\title{
CYCLONE DISASTER ON HOUSING AND COASTAL AREA
}

\section{P. Malleswararao}

Principal,SITAM Engg College, Vizianagaram, Former Head of Civil Engg Dept., Andhra University, Visakhapatnam

\begin{abstract}
Cyclones are the Natural hazards which create huge economic loss and loss of Lives..In the present study, the orision of cyclones in the months of May, October and November are discussed.The cyclone tracks in the month of November for the past 100 years is presented. The Delta areas of major rivers, Eastern ghats, thechanges in Environmental conditions of an area and changes in Temparatue will contribute in deciding the cyclone tracks. The pressure distribution and stress distribution around the roof and walls of a pitched roof house is discussed. It is also noted that the design wind speed of coastal area of East coast in the IS code shall be revised due to increase in wind speed of the recent super cyclones.
\end{abstract}

$* * *$

\section{INTRODUCTION}

Occurrences of manmade and natural hazards have been increasing year by year. Due to this phenomenon; huge economic losses as well as loss of human lives have been increasing at an alarming rate. Developed countries are substantially mitigation losses arising out of disasters. Developing counters especially south Asian countries like India, Bangladesh, Pakistan etc., generally experience cyclones, hurricanes and floods frequently, as these became annual phenomena in these countries. The hurricanes and cyclones create havoc situation in various spheres, damaging crops, roads, houses etc., and leading to huge economic losses in these countries. Besides this, the cyclones and the hurricanes significantly contribute to flooding in these regions and further intensify the economic losses as well as many losses of life.

As per the Meteorological department studies, on an average, 3 cyclones are being formed per annum in our country, of which one cyclone would be severe in nature. As a result huge economic losses are registered during cyclones, especially in the east coast region of the country. Andhra Pradesh is one of the important states affected by cyclones hurricanes and floods registering huge economic losses as per every year. In May 1990, a severe cyclone caused huge economic losses as per the revenue department estimate, about Rs. 1,274.93 crores in the state of Andhra Pradesh. The, maximum loses are found about Rs.388.32 crores due to house damages, Rs. 334.89 crores due to crop damages and Rs. 270.90 crores due to roads damages during this cyclone. Further, the compensation paid by the State Government for the development of houses is about Rs. 490.01 crores.

\section{TRACKS OF CYCLONIC STORMS ALONG THE EAST COAST OF INDIA}

The tracks of various cyclonic storms in the Bay of Bengal are studied month wise from the year 1891 to 19997 . The total numbers of cyclonic disturbances originated from Bay of Bengal during the period from year 1891 to 1997 were 1256. In which, total number intensified into storms were 457. Most of the storms originated in the months of May, October and November.

Andhra Pradesh state having a coastline of $974 \mathrm{Kms}$ is subjected to cyclones and storms now and then. From the study on tracks of cyclonic storms, it is observed that nearly $16 \%$ of tracks of cyclonic storms are crossed in coastal A.P. Most of the cyclones generally occur in the months of May, October and November and are very less during other months.

Cyclones crossed in various coastal districts of Andhra Pradesh during months of May, October and November from the year 1981 to 1997 are presented in table 1.

May: There is an appreciable increase in the frequency of storms from April to May. Most of the Bay storms originate between $10^{\circ} \mathrm{N}$ and $15^{\circ} \mathrm{N}$; move initially in a northwesterly or northerly direction and the recurve towards the northeast. The whole of the East Coast of India, the coastal areas of Bangladesh and the Arakan coast of Burma are liable to incidence of storms in this month (Atlas of tracks of storms and depressions in the Bay of Bengal and Arabian sea from 1887 to 1970). Total number of cyclonic disturbances originated from Bay of Bengal during this month from Year 1981 to 1997 were 88 (i.e. nearly $7 \%$ of cyclones originated).

The total number of cyclones crossed the coastal A.P. during this month were 9 (i.e., nearly $10 \%$ of cyclones crossed). Most of the above cyclones crossed the coasts of West Godavari, Krishna and Nellore Districts.

October: In this month storms in the Bay of Bengal originated between $8^{\circ} \mathrm{N}$ and $14^{\circ} \mathrm{N}$. they move initially in a northwesterly direction. Most of them later recurve and move towards Northeast. The north Tamil Nadu and Andhra coasts and the coastal Belt of Bangladesh are particularly vulnerable to the incidence of storms in this month. Most of 
the storms that strike the coast south of $15^{\circ} \mathrm{N}$ enter the Arabian Sea and re-intensify (Atlas of tracks of storms and depressions in the Bay of Bengal and Arabian Sea from 1877 to 1970). Total numbers of cyclonic disturbances originated from Bay of Bengal during this month from year 1891 to 1997 were 189(i.e. nearly $15 \%$ of cyclones originated).

It is noted that, total number of cyclones crossed the coastal A.P. during the month of October were 44 (i.e. nearly $23 \%$ of cyclones crossed). Most of the above cyclones crossed the coasts of West Godavari, Krishna and Prakasam districts.

November: The source region of the majority of the storms during this month is between $8^{\circ} \mathrm{N}$ and $13^{\circ} \mathrm{N}$. These move in a west-northerly direction and strike the North Tamil Nadu and adjoining south Andhra coast and emerge in to the Arabian Sea where they re-intensify. Bay storms, which form in more northerly latitudes move northeast and later recurve towards the Northeast (Atlas of tracks of storms and depressions in Bay of Bengal and Arabian Sea from 1877 to 1970). Total number of cyclonic disturbances originated from Bay of Bengal during this month year 1891 to 1997 were 160 (i.e. nearly 13 of cyclones originated).

It is observed that, total number of cyclones, crossed the coastal A.P. during this month were 24 (i.e. nearly $15 \%$ of cyclones crossed). Most of the above cyclones crossed the coasts of Krishna, Prakasam and Nellore districts.

From above study, it is noted that most of the cyclonic storms are crossing the East Coast between Visakhapatnam and Madras. Most of the crossing points are very nearer to Kakinada, Machilipatnam, Ongole and Nellore. The coastal area from East Godavari district to Nellore district is at low level when compared to other districts in coastal A.P. (i.e. Srikakulam, Vizianagaram and Visakhapatam districts). As per the tracks of the cyclonic storms, it is noted severe storms are crossing the land either between Kakinada and Madras or the coast of West Bengal and Bangladesh. Hence the area between Kakinada and Madras is cyclone track area.

\section{HISTORIC INCIDENTS OF STORMS}

Storms including disastrous sea waves were of common occurrence in the past. Though such events may appear to be catastrophic in an individual lifetime they are common events in terms of geologic history. Two or three cyclones in an year are of common occurrence in the Bay of Bengal. High energy storms battered the Andhra coast six times during $25^{\text {th }}$ November $1922,18^{\text {th }}$ November $1933,18^{\text {th }}$ November 1938, 6th and $7^{\text {th }}$ November 1969, 19th November 1977 and 6th November 1996 with the last seven decades. Among these cyclones, 19 ${ }^{\text {th }}$ November 1977 cyclone is very sever cyclone. An area of 700 sq.km was affected by severe sea waves in Divi Island in Krishna district in $19^{\text {th }}$ November 1977 , killing thousands of people and cattle. A number of sluiceways were opened along the coastal barrier spreading erode sand on tidal flats as sand lobes. At places, the seawater deposited $2.5 \mathrm{~cm}$ of silt in cultivable lands.

The cyclones, in the months of April - May form in the Bay of Bengal and move west or North and cross East Coast and hit Bangladesh and Burma. Six cyclonic storms hit the Andhra coast during summer period are given below.
1. May $26^{\text {th }}, 1904$ - West Godavari District
2. May $15^{\text {th }}, 1914-$ Srikakulam District
3. May $16^{\text {th }}, 1925-$ Krishna District
4. May $19^{\text {th }} / 20^{\text {th }}, 1940-$ Nellore District
5. May $7^{\text {th }}, 1979-$ Guntur District
6. May $6^{\text {th }}, 1990-$ Krishna District

\section{CYCLONE AND FLOOD DAMAGES IN} VARIOUS DISTRICTS OF COASTAL ANDHRA

\section{PRADESH:}

Cyclone and flood damage data in various districts of coastal Andhra Pradesh has been collected and the important cyclones and floods are discussed below.

\section{NOVEMBER, 1977 CYCLONE IN KRISHNA AND GUNTUR DISTRICTS:}

A severe cyclonic storm crossed the East Coast at Ponnuru nearer to Machilipatnam on $19^{\text {th }}$, November 1977 affecting the coastal districts of Krishna and Guntur severely and Godavari districts partially. The sea waves crossed a $125 \mathrm{~km}$ strip of the deltaic coast raising the sea water level up to $8 \mathrm{~m}$ between $3 \mathrm{PM}$ and 8.30 PM. The sea waves penetrated $12 \mathrm{~km}$ inside the low-lying coastal plains and inundated 700 sq.km of area in Divi and Machilipatnam Taluks. About 1lakh acres of standing crops were submerged. Nearly 10,000 lives were believed to have been lost. Loss of life among livestock was very much. The telephone poles of $6 \mathrm{~m}$ height trapped hay and slush carried by the waves near Nagayalanka. The wind velocities are above $140 \mathrm{kmph}$. The wave actions coupled with storm surge were the main agencies for the destruction of property and loss of life. Old trees were uprouted telephone and electrical poles were twisted and bent down in many places. Asbestos roofed industrial units and thatched houses were blown and rawaged to the ground. The storm surge destruction in Divi and Machilipatnam taluks was heavy, wiping out 55 villages in the process, except for concrete structures like school buildings and temples.

\section{0 cyclone and flood in Srikakulam district:}

It was one of the severe cyclone and flood in this district. Due to this, about 2,23,608 persons were affected and also 88 persons died. About 33,811 houses were damaged and 26,068 cattle were lost. Thousands of hectares of crop, roads and electric lines were damaged. The Howrah - Madras 
railway line was breached near Urlan station; railway bridges across Nagavali and Vamsadhara rivers were damaged. The national high way was breached at several places. Thatched houses were washed away. All the damages were happened in the flood plain areas of Vamsadhara and Nagavali rivers.

Relief measures: The railway bridges of Vamsadhara and Nagavali were immediately repaired and the breached railway embankments were closed. The breaches in the national high way were also closed.

Measures needed: During floods the railway embankments and national high way embankments acted as barriers for flood flow. So sufficient waterways are needed in these reaches of flood plain areas of the rivers.

Hence additional bridges are to be constructed abutting the bridges across the rivers, to accommodate the flood flows.

\section{FLOOD \& CYCLONE IN SRIKAKULAM DISTRICT}

Due to this, about 4lakh people were affected and 30 persons died. About 15,548 houses were damaged and 212 cattle were lost.

\section{NOVEMBER 1995 FLOOD / HEAVY RAINS IN VIZIANAGRAM DISTRICT}

Due to this, 13 persons were died. About 2,632 houses were damaged and 2 cattle were lost. About 8,450 hectares crop and roads were damaged.

\section{$\begin{array}{llll}\text { OCTOBER } & 1995 & \text { CYCLONE IN }\end{array}$}

\section{VISAKHAPATNAM DISTRICT}

Due to this cyclone, population effected is 794 families and 4 persons were died. About 6,093 houses were damaged and also 6 cattle were lost. About 10,542 hectares crop was damaged

\section{NOVEMBER, 1996 CYCLONE STORM IN EAST GODAVARI DISTRICT}

A cyclone storm started in the Bay of Bengal on $5^{\text {th }}$, November 1996 and moved westerly and crossed the Andhra coast near to Kakinada. The wind speeds recorded were of the order $220 \mathrm{kmph}$. This is a severe cyclonic storm with a core of hurricane winds. The numbers of deaths reported in East Godavari district were 978 and numbers of persons missing were 1,683. Numbers of houses fully damaged were 2,58,389 and partially damaged were $1,84,718$. Numbers of fishermen affected were 18,685 . Numbers of crafts lost were 7,158 and numbers of crafts damaged were 4,464 . The crop area fully damaged $1,17,519$ hectares and number of farmers affected were 3,04,264. The numbers of coconut trees fully damaged were $43,54,459$ and partially damaged were $28,07,229$, in an area of 90,832 acres. In addition to the above, banana planted in an area of 23,248 acres was completely damaged. The damages are due to high-speed winds. The roof stops of thatched houses and tiled houses were blown away. The heads of the coconut trees were cut.

Relief measures: some of the thatched houses were converted into tiled houses. Permanent houses with R.C.C slab were constructed in the places of thatched and tiled roof houses. New coconut plants were planted in the damaged coconut gardens.

Measures needed: Most of the area of East Godavari district is lying below $+10 \mathrm{~m}$. contour. This area is susceptible for floods of Godavari River and also cycloneinduced floods due to rise in wave heights (storm surges etc.). Most of the storms crossing are also through this district. Hence the following measures are further needed.

1. The plinth levels of all the buildings in these areas should be as high as possible.

2. All the houses in the rural and urban should be converted into R.C.C. roofed houses.

3. The electrical lines to each village in these areas should be provided with underground electrical cables to prevent the damages caused to the electrical poles and wires.

4. In the Godavari River flood prone area, high-level earthen mounds abutting the villages are needed, to keep the cattle and public during the floods

\section{SEPTEMBER / OCTOBER 1998 FLOOD / HEAVY RAINS IN GUNTUR DISTRICT}

Due to this, population was affected in 174 villages and 24 persons were died. About 12,292 houses were damaged. About 61,174 hectares crop was damaged.

\section{PYLON CYCLONE DURING 2013}

Cropfs in North coastal districts were badly damaged due to this cyclone

\section{HUD HUD CYCLONE DURING OCTOBER 2014}

The Hud Hud cyclone crossed the East coast at Visakhapatnam on $12^{\text {th }}$ October 2014 through Megadrigedda River basin. The obsereved wind velocity is more than 230 Kmph. The track of Hud Hud cyclone is shown in Figure 4. Many trees were uprooted and the remaining trees became branch less. The roofs of many buildings such as airport building, Convocation theatre ,auditorium ,Film Theater buildings with sheet roofing are blown away. Electrical towers and major towers are fallen down. Entire electrical net work is completely damaged. Several berths in Ports are damaged. Core material of the Break waters is washed out. RamaKrishna beach is eroded. Many Industries are damaged. Thus, this cyclone caused huse economic loss in the North coastal districts. 
Many compound walls collapsed due to boundary layer separation and formation of negative pressure at the rear side of the wall when wind is blowing with very high speeds. The compound walls with weak jointing collapsed.

Even though the number of cyclones passing through Visakhapatnam are scanty in the past, the changes in the environmental conditions such as heat liberated from the industries coupled with Meghadrigedda river basin might have attracted the path of Hud Hud cyclone.

\section{EFFECT OF LOW PRESSURE ON THE COASTAL EROSION:}

Due to low pressue, there will be rise in the water level of the sea. Due to this ,the wave breaking advances towards the shore and cause erosion of the beach material.

Based on above discussion, it is noted that the damages caused by the cyclones are more due to winds than floods.

Due to cyclones, the coastal area experienced not only heavy rainfall, but also winds with very high speeds generally from sea to land side, which is in opposite direction to the river flows (flood flows). This type of wind motion will generate high sea waves in the order of $3 \mathrm{~m}$ to $8 \mathrm{~m}$. These high sea waves block the free flow of flood water, which in turn inundate the low lying coastal areas. The maximum sea level raised during 1977 cyclone was $8 \mathrm{~m}$. At that time, the coastal areas near Deviseema were marooned. From the above observations it is noted that the coastal area below $10 \mathrm{~m}$ is subjected to cyclonic floods and storm surges. Hence a $10 \mathrm{~m}$ contour was marked along the coast of A.P. to identify the cyclone flood prone area.

The contours at $10 \mathrm{~m}$ level and $50 \mathrm{~m}$ level along the coastal area of A.P. are studied and it is noted that the towns and villages situated below $10 \mathrm{~m}$ contour in the coastal. A.P. are prone to floods. Godavari and Krishna deltas are more flood prone regions because more area is situated below $10 \mathrm{~m}$ contour.

\section{EFFECT OF THE EASTERN GHATS ON CYCLONIC TRACKS}

The Eastern Ghats starts from the Vaigai valley in the south and runs nearly parallel to the East coast upto Mahanadi valley in the north. The cyclonic storms cross the ECI at the delta region of the Brahmaputra - Ganges, the Mahanadi, the Godavari, the Krishna, the Pennar and the Cauvery. The storms pass further northwestwards through the respective river valley and generally turn northwards. The cyclonic disturbances are less between Pentakota (East Godavari Dt.) and Baruva (Srikakulam Dt.) because the Eastern Ghats run near and into the Bay of Bengal.

The Eastern Ghats act as barriers, to the storm tracks. The maximum elevation in different parts of the Eastern Ghats in AP are at - Mallama Konda, 893m (Pennar); Papikonda, 679m (Godavari); Cherukonda, 1441m; Arma Konda, 1680m; Nimgiri, 1515m; Singarazu Parbat, 1516m; Mahendra Giri, (near Mandasa) 1510m. In the Krishna delta, the Eastern Ghats are far from the ECI and have altitudes less than $550 \mathrm{~m}$. Therefore,the tracks that cross the Krishna delta region travel westward into Telangana Plateau.

\section{PRESSURE DISTRIBUTION AND STRESS DISTRIBUTION AROUND HOUSE MODEL:}

Experiments are conducted on various types of House models in the wind tunnel with different wind speeds. The pressure distribution around the House models is measured and the stress distribution and deflection on the roofs and outside walls are computed using ANSYS.The stress distribution on a pitched roof house model due to wind velocity of $30 \mathrm{~m} / \mathrm{s}$ is shown in figure 2 . Deflection on the roof and side walls is shown in figure 3 . It is noted that when wind is blowing with very high speed over the buildings, suction pressure induces over the roof and on the rear side walls. Hence during cyclones, for blowing of roof sheets suction pressure is the main cause in the leeward side.

\section{CONCLUSIONS}

1. Most of the cyclones are originating between the latitudes $8^{\circ} \mathrm{N}$ and $15^{\circ} \mathrm{N}$, and longitudes between $85^{\circ} \mathrm{E}$ and $95^{\circ} \mathrm{E}$ which is near to the path of sun receiving high heat radiation from sun.

2. The cyclone tracks mostly cross the coast at the estuary points of the rivers. The areas surrounding the cyclone tracks are subjected to heavy rainfall and wind. As a result the rivers in these areas will experience floods whenever there is severe cyclonic storm.

3. Due to existence of Eastern Ghats, the area between Pentakota (East Godavari) and Baruva (Srikakulam Dt.) are less prone to cyclone tracks. But, the delta areas of the rivers - Cauvery, Pennar, Krishna, Godavari, Mahanadi, Ganga and Brahmaputra - are cyclone track prone areas.

4. As per IS 875 for wind loads, the design wind speed for Visakhapatnam coastal region is $180 \mathrm{kmph}$. But the observed wind speeds as per Orissa super Cyclone,Hud Hud cyclone, are more than $230 \mathrm{kmph}$. Hence, the IS code provision for design wind speed shall be revised for designing the structures in the coastal areas.

5. The changes in the Environmental conditions of an area such as industrialization and changes in temparaure conditions attract the cyclone tracts towards that area.

6. The rise in sea level due to low pressure development will lead to coastal erosion by advancing the wave breaking towards the beach.

\section{REFERENCES}

1. IMD, 1979, The tracks of storms and depressions in the Bay of Bengal and the Arabian Sea 18771970 . 
2. IMD, 1996, The tracks of storms and depressions in the Bay of Bengal and the Arabian Sea 19711990. An Addendum to the Storm Track Atlas (1877-1970).

3. Malleswara Rao, P., Srinivasu, V., Srinivasa Rao, G., 1999 ' Cyclone and flood Hazards in the East Godavari district of Andhra Pradesh ', 5. Proceedings of the National seminar on Disaster
Management, November 12-13, 1999, Dep., of Civil Engineering, University College of Engineering, Burla, Orissa, I-1 to I-10.

4. NATMO, 1981, National Atlas\&Thematic MappingOrganisatio(NATMO) Department of Science \& Technology, Government of India, Vol. II

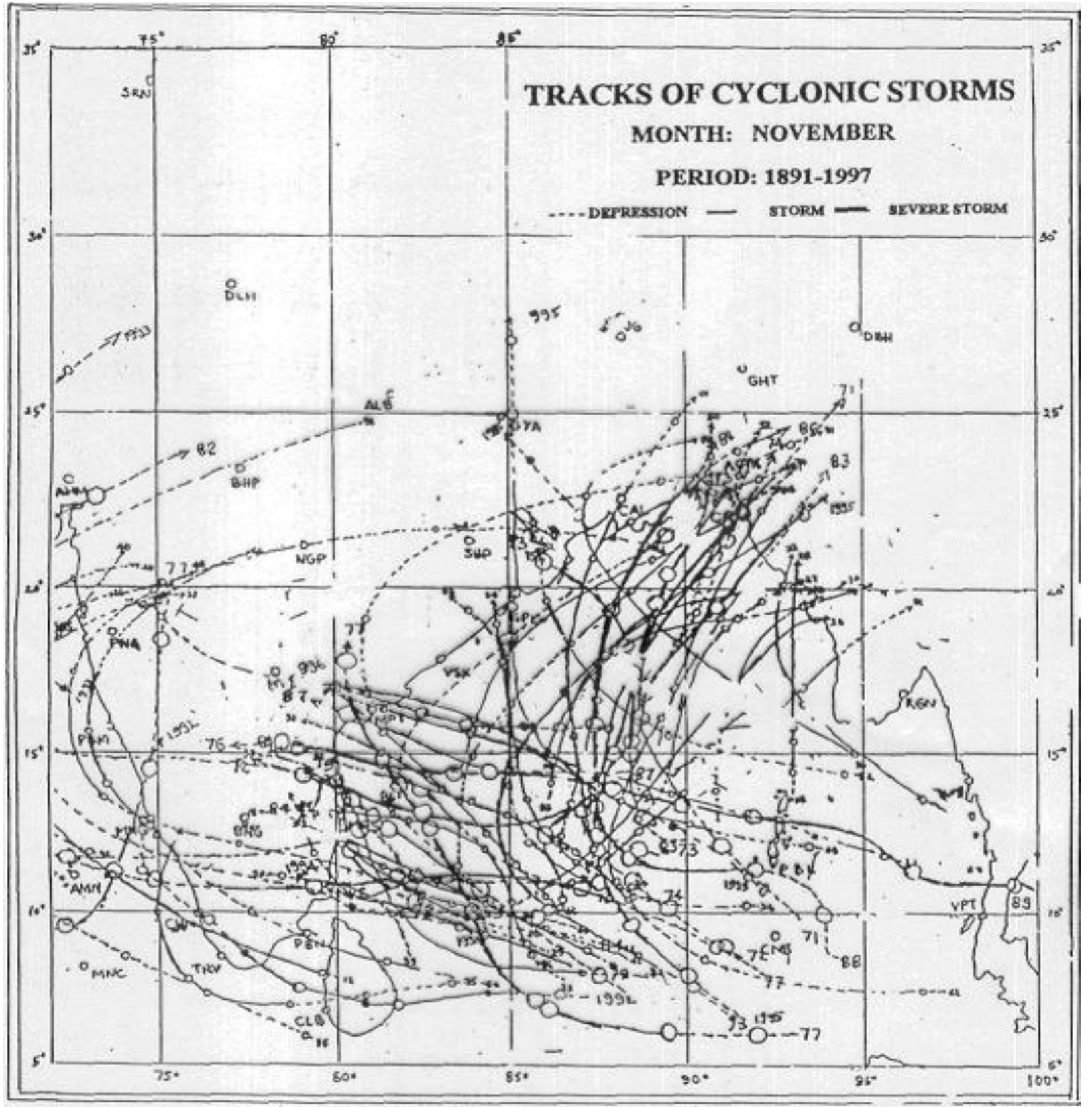

Fig1. Cyclone tracks crossed in the Month of November 
Table 1: Cyclones croseed In cosetal dletricts of Andhra Pradesh, Orlesa, West Bengal and Bangladesh during monthe of May and November from the year 1891-1997

\begin{tabular}{|c|c|c|c|c|}
\hline $\begin{array}{l}\text { Name of the } \\
\text { DistrictiArea }\end{array}$ & 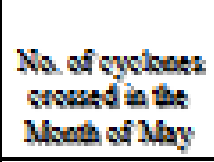 & 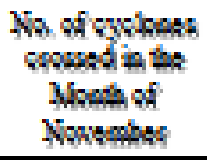 & $\begin{array}{l}96 \text { of cyslopes } \\
\text { srowsd in the } \\
\text { Month of may }\end{array}$ & 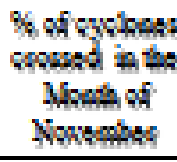 \\
\hline Srilkakdalam & 0 & 2 & 0 & 1.63 \\
\hline Virianagaram & 0 & 9 & 0 & 9 \\
\hline Visathapatanm & 8 & 1 & 0 & 1,63 \\
\hline Eant Godavari & 1 & $\theta$ & 2.23 & $\theta$ \\
\hline Went Godavasi & 2 & 2 & 4.48 & 327 \\
\hline Krishas & 2 & 3 & 4.43 & 2124 \\
\hline Guantor & 1 & 2 & 2.23 & 1.60 \\
\hline Pralanam & 1 & 6 & 2.23 & 933 \\
\hline Netlore & 2 & 6 & 4.43 & 9.39 \\
\hline $\begin{array}{l}\text { Nollore: } \\
\text { Nagaparam }\end{array}$ & 10 & 23 & 44.43 & 38 \\
\hline Goppalpor = Calerun & 8 & 4 & 13.34 & 6.38 \\
\hline Calcutha - Alyyab & 20 & 20 & 44.49 & 264 \\
\hline Total & 43 & 60 & & \\
\hline
\end{tabular}

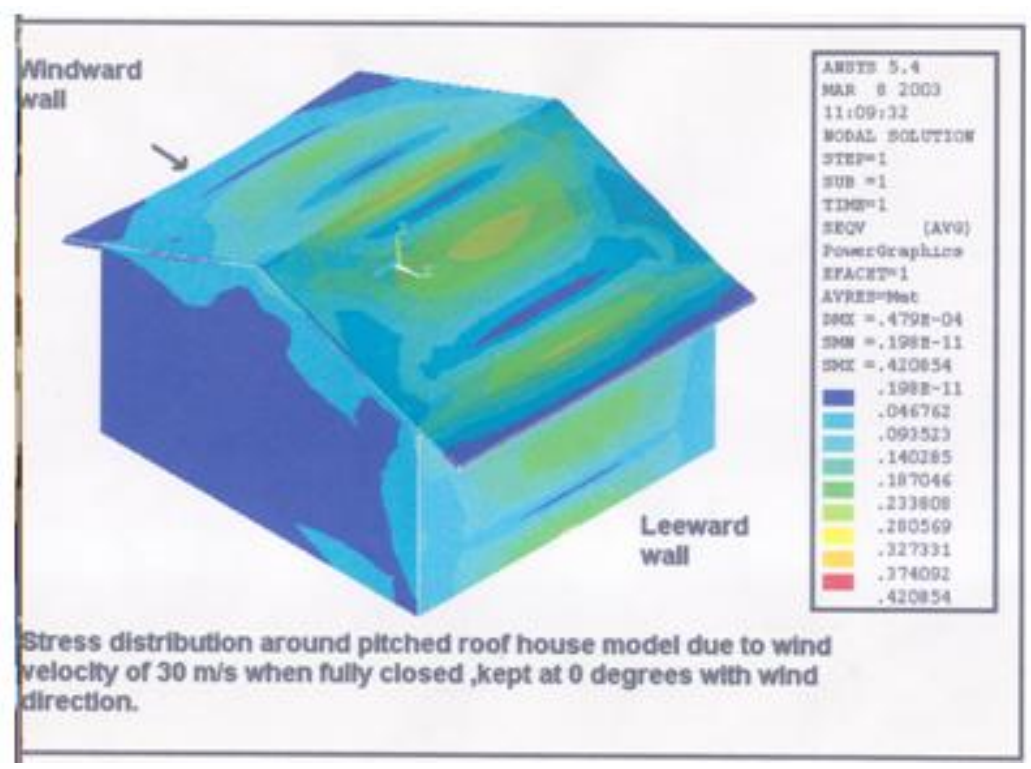

Figure 2: Stress distribution around pitched roof house model 


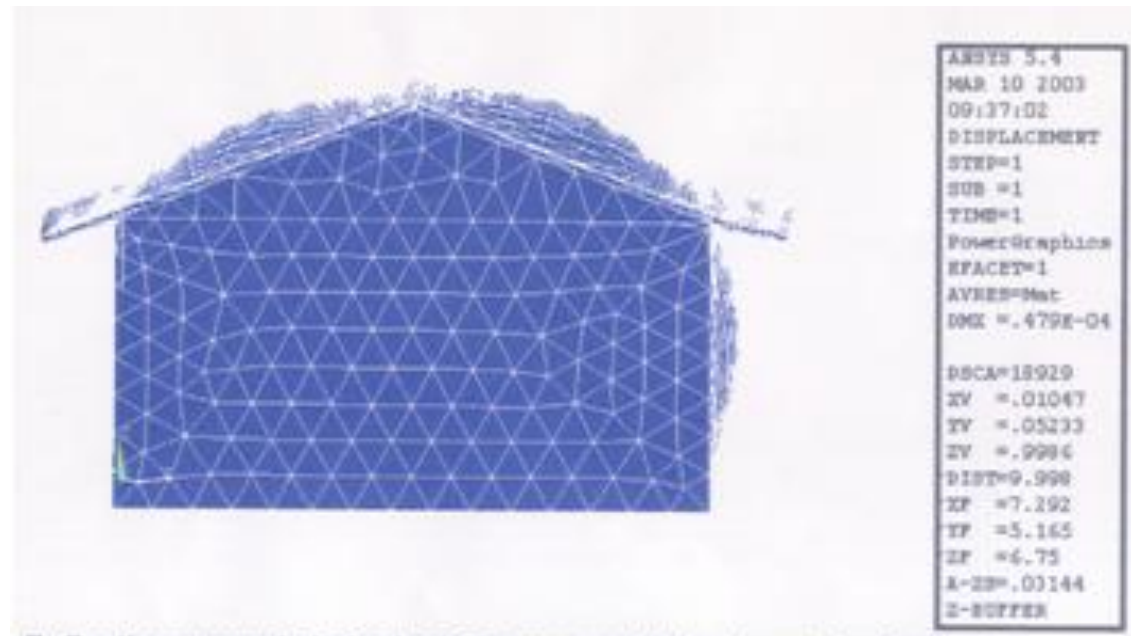

Deflection around pitched roof house model due to wind velocity of $30 \mathrm{~m} / \mathrm{s}$ when fully closed kept at 0 degrees with wind direction.

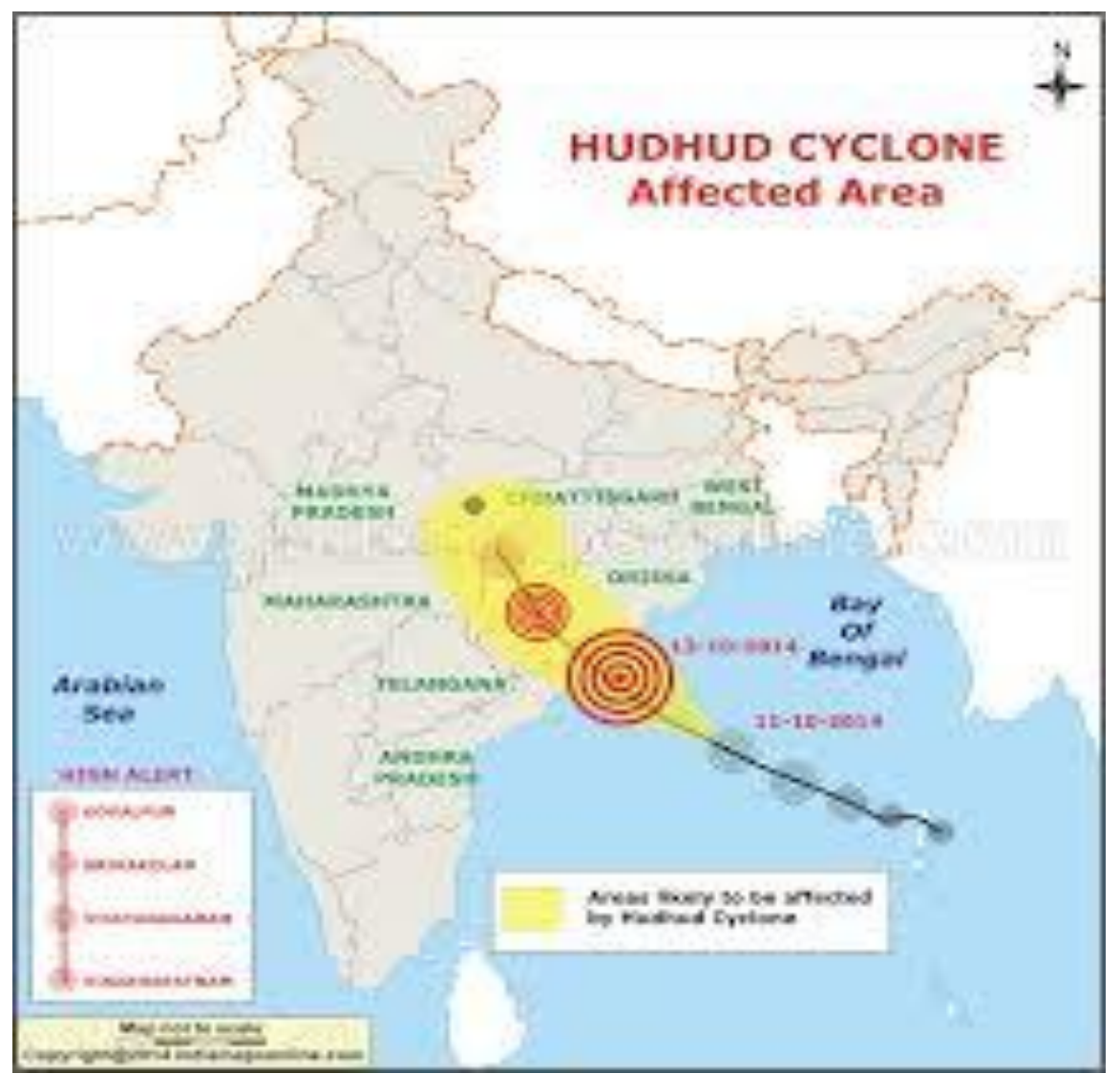

Figure 4: Track of Hud Hud cyclone 